\section{OAK RIDGE NATIONAL LABORATORY}

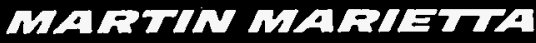

\title{
Creep Analysis of Fuel Plates for the Advanced Neutron Source
}

\author{
W. F. Swinson \\ G. T. Yahr
}

August 1994

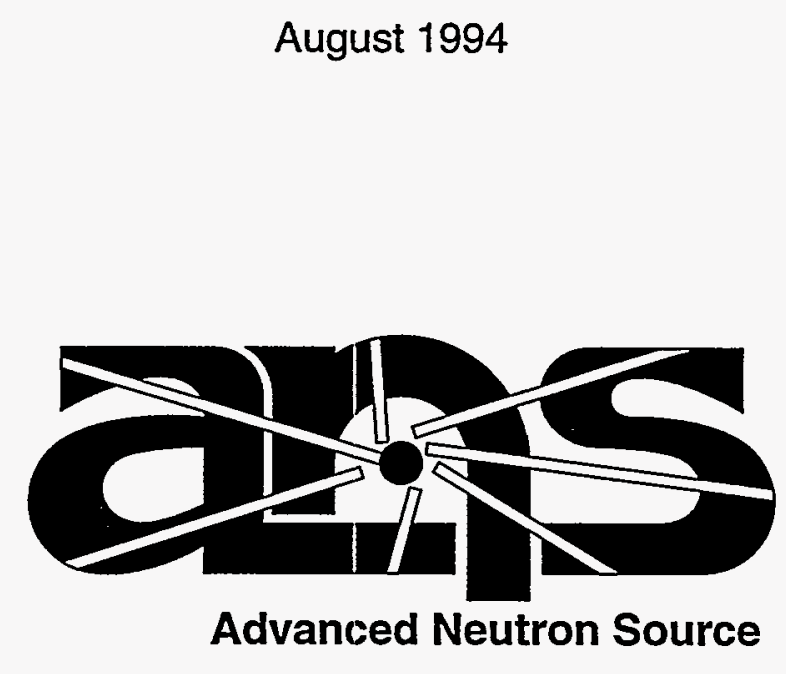

MANAGED BY

MARTIN MARIETTA ENERGY SYSTEMS, INC.

FOR THE UNITED STATES

DEPARTMENT OF ENERGY 
This report has been reproduced directly from the best available copy.

Available to DOE and DOE contractors from the Office of Scientific and Technical Information, P.O. Box 62, Oak Ridge, TN 37831; prices available from (615) 576-8401, FTS 626-8401.

Available to the public from the National Technical Information Service, U.S. Department of Commerce, 5285 Port Royal Rd., Springfield, VA 22161.

This report was prepared as an account of work sponsored by an agency of the United States Government. Neither the United States Government nor any agency thereof, nor any of their employees, makes any warranty, express or implied, or assumes any legal liability or responsibility for the accuracy, completeness, or usefulness of any information, apparatus, product, or process disclosed, or represents that its use would not infringe privately owned rights. Reference herein to any specific commercial product, process, or service by trade name, trademark, manufacturer, or otherwise, does not necessarily constitute or imply its endorsement, recommendation, or favoring by the United States Government or any agency thereof. The views and opinions of authors expressed herein do not necessarily state or reflect those of the United States Government or any agency thereof. 


\section{DISCLAIMER}

Portions of this document may be illegible in electronic image products. Images are produced from the best available original document. 
ORNL/TM-12788

Engineering Technology Division

\title{
CREEP ANALYSIS OF FUEL PLATES FOR THE ADVANCED NEUTRON SOURCE
}

\author{
W. F. Swinson
}

G. T. Yahr

August 1994

(Date published: November 1994)

Prepared by

OAK RIDGE NATIONAL LABORATORY

Oak Ridge, Tennessee 37831

managed by

MARTIN MARIETTA ENERGY SYSTEMS, INC.

for the

U.S. DEPARTMENT OF ENERGY

under contract DE-AC05-84OR21400

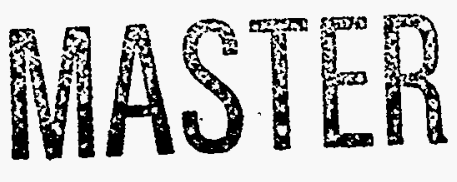

DISTRIBUTION OF THIS DOCUMENT IS UNLIAAITED 



\section{CONTENTS}

\section{Page}

LIST OF FIGURES..........................................................................................................

LIST OF TABLES........................................................................................................ vii

ACRONYMS AND SYMBOLS ….......................................................................... ix

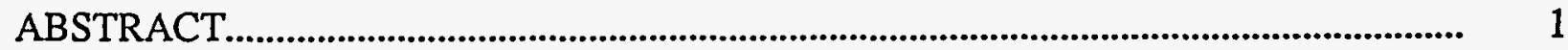

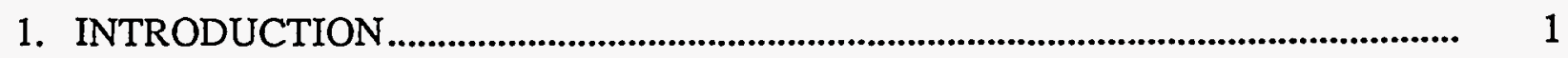

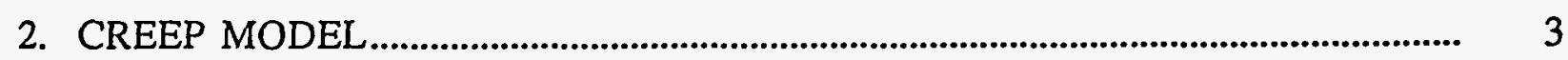

3. CREEP SOLUTION SCHEME _........................................................................ 11

4. STRESS ANALYSIS WITH THE CREEP MODEL .................................................... 21

5. SUMMARY ................................................................................................................ 29

6. REFERENCES …….................................................................................................. 31

APPENDIX A: CASTIGLIANO'S THEROREMS FOR A BEAM IN BENDING........ A-1 
. 


\section{LIST OF FIGURES}

Figure

Page

1 Isochronous stress strain curves $6061-0$ aluminum $177^{\circ} \mathrm{C}$...................................... 4

2 Isochronous stress strain curves $6061-0$ aluminum $204^{\circ} \mathrm{C}$..................................... 5

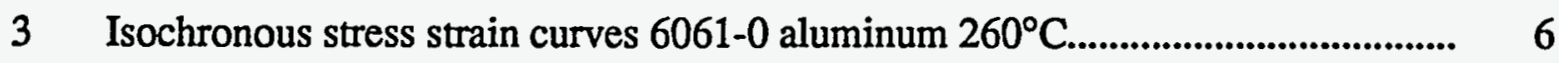

4 Isochronous data approximation I $6061-0$ aluminum $260^{\circ} \mathrm{C}$ and 450 hours .......... $\quad 8$

5 Isochronous data approximation II $6061-0$ aluminum $260^{\circ} \mathrm{C}$ and 450 hours......... $\quad 9$

6 Beam element.............................................................................................. 12

$7 \quad$ Involute forces and geometry .................................................................................. 16

8 Beam element deformation ........................................................................ 18

$9 \quad$ Free body of longitudinal thermal forces................................................................ 27

A.1 Beam element.......................................................................................... A-4 


\section{LIST OF TABLES}

Table

Page

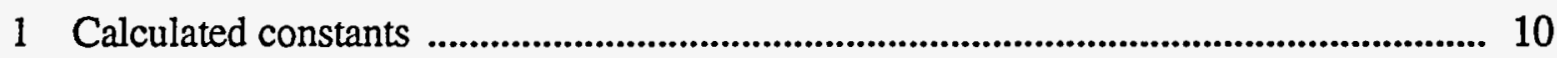

2 Maximum involute plate deflection............................................................................. 20

3 Transverse plate stresses resulting from pressure ............................................................ 22

4 Maximum transverse stress from combined pressure and thermal load....................... 26

5 Maximum longitudinal stress from thermal load .......................................................... 28 


\section{ACRONYMS AND SYMBOLS}

ANS Advanced Neutron Source

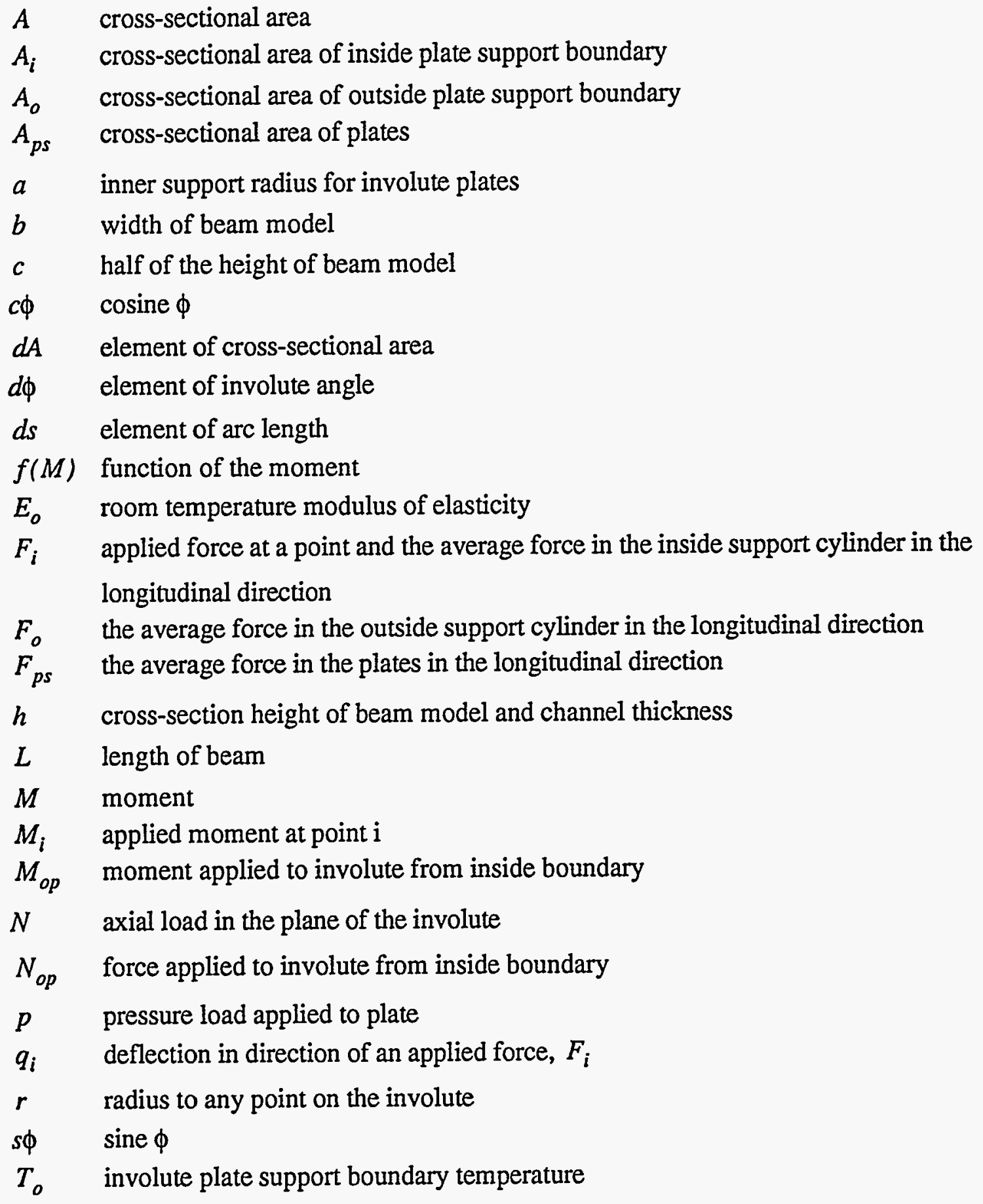


$T_{p s} \quad$ involute plate temperature

$V \quad$ flow velocity

$V_{o p} \quad$ shear load applied to involute

$x \quad$ involute coordinate

$y \quad$ involute coordinate and in the beam model cross-section the distance from neutral axis to the point in question

$y_{\ell} \quad$ the y-coordinate projection of the plate

$\alpha \quad$ coefficient of thermal expansion

$\delta_{i} \quad$ deflection at a point on a structure and average longitudinal displacement of the inside support

$\delta_{j} \quad$ deflection of beam at point " $j$ "

$\delta_{o} \quad$ average longitudinal displacement of the outside support

$\delta_{p s} \quad$ average longitudinal displacement of the plates

$\Delta_{j}, \Delta_{i}, \quad$ deflection of one end of a straight beam segment relative to the other end for elements $j, i$,

$\Delta_{1}, \Delta_{2} \quad 1,2$

$\Delta_{p} \quad$ pressure differential across a plate

$\Delta s, \Delta s_{i}$ element arc length and element of arc length at point " $i "$

$\Delta T \quad$ temperature difference between plate and boundary

$\varepsilon \quad$ normal strain

$\varepsilon_{\text {Nop }} \quad$ strain caused by the boundary load, $N_{\text {op }}$

$\varepsilon_{o} \quad$ constant

$\varepsilon_{p s} \quad$ average normal strain in the plates

$\gamma \quad$ complementary energy in a structure

$v$ coolant kinematic viscosity

$\phi \quad$ involute angle

$\phi_{i} \quad$ involute angle at point " $i$ "

$\phi_{\ell} \quad$ involute angle at end of involute

$\rho \quad$ coolant density and radius of curvature because of plate deformation

$\rho_{i} \quad$ deformed radius of curvature at point " $i$ "

$\sigma \quad$ normal stress

$\sigma_{d} \quad$ specified stress level

$\sigma_{o} \quad$ constant

$\sigma_{p s}$ the average normal stress in the plates

$\Theta \quad$ angle subtended by a deformed beam element

$\Theta_{i} \quad$ rotation of couple

$\Delta \Theta_{i}$ rotation at a point on a structure because of an applied moment $M_{i}$ 


\title{
CREEP ANALYSIS OF FUEL PLATES FOR THE ADVANCED NEUTRON SOURCE
}

\author{
W. F. Swinson \\ G. T. Yahr
}

\begin{abstract}
The reactor for the planned Advanced Neutron Source will use closely spaced arrays of fuel plates. The plates are thin and will have a core containing enriched uranium silicide fuel clad in aluminum. The heat load caused by the nuclear reactions within the fuel plates will be removed by flowing high-velocity heavy water through narrow channels between the plates. However, the plates will still be at elevated temperatures while in service, and the potential for excessive plate deformation because of creep must be considered. An analysis to include creep for deformation and stresses because of temperature over a given time span has been performed and is reported herein.
\end{abstract}

\section{INTRODUCTION}

Nuclear reactions within the Advanced Neutron Source (ANS) fuel plates increase the plate temperatures. Estimates for these temperatures (supplied by the thermal-hydraulics group) include an average upper element plate temperature of $191^{\circ} \mathrm{C}\left(376^{\circ} \mathrm{F}\right)$ and an average lower element plate temperature of $140^{\circ} \mathrm{C}\left(284^{\circ} \mathrm{F}\right)$. In addition, the maximum temperature anticipated for the upper plates is $290^{\circ} \mathrm{C}\left(554^{\circ} \mathrm{F}\right)$, and the maximum temperature anticipated for the lower plates is $206^{\circ} \mathrm{C}$ $\left(403^{\circ} \mathrm{F}\right)$. Because of these temperatures, maintained over an expected plate life of $408 \mathrm{~h}$, some assessment of the plate creep is needed in evaluating the structural integrity of the plates. Creep produces two different effects in a structure. If the structure is loaded by a constant displacement of the boundaries, the stresses relax with time. If the structure is loaded by an applied force and the force is held constant, deformation of the structure increases with time. An example of the first case is seen in the thermal deformation caused by the plates being at higher temperatures than the support cylinders: in this case, the plates reach a certain maximum stress state and then relax with time. An example of the second case is the pressure differential between adjacent channels exerting a relatively constant load on a plate: in this case, the deformation increases with time. 


\section{CREEP MODEL}

In developing a model to predict the effects of creep, the plate is treated as an involute beam with the pressure load established empirically ${ }^{1}$ from the fuel plate flow experiments as

$$
\frac{\Delta p}{\rho V^{2}}=0.040\left(\frac{V h}{v}\right)^{0.177},
$$

where

$$
\begin{aligned}
\Delta p & =\text { average pressure difference across a plate } \\
\rho & =\text { coolant density } \\
V & =\text { coolant flow velocity }(25 \mathrm{~m} / \mathrm{s}) \\
h & =\text { channel thickness } \\
v & =\text { coolant kinematic viscosity }
\end{aligned}
$$

In the elastic analysis of the fuel plates, modeling the plate as a beam correlated with experimental measurements; therefore, a beam model is used for this creep analysis. Isochronous stress-strain data for aluminum 6061-0, Figs. 1-3,2 are used to relate stress to strain at a given time and temperature. The data are approximated with a hyperbolic sine function

$$
\sigma=\sigma_{o} \operatorname{arc} \sinh \left(\frac{\varepsilon}{\varepsilon_{o}}\right)
$$

where

$$
\begin{aligned}
& \sigma_{o} \text { and } \varepsilon_{o} \text { are constants, } \\
& \sigma=\text { normal stress, } \\
& \varepsilon=\text { normal strain. }
\end{aligned}
$$

The approach is to establish the constants of Eq. (2) from experimental data corresponding to a given time and temperature. With this stress-strain relation, solutions for the stress, strain, and deformation are sought in a structure. To assess the amount of creep, find the calibration constants of Eq. (2) from data at the same temperature but with a different time, and again seek solutions for 


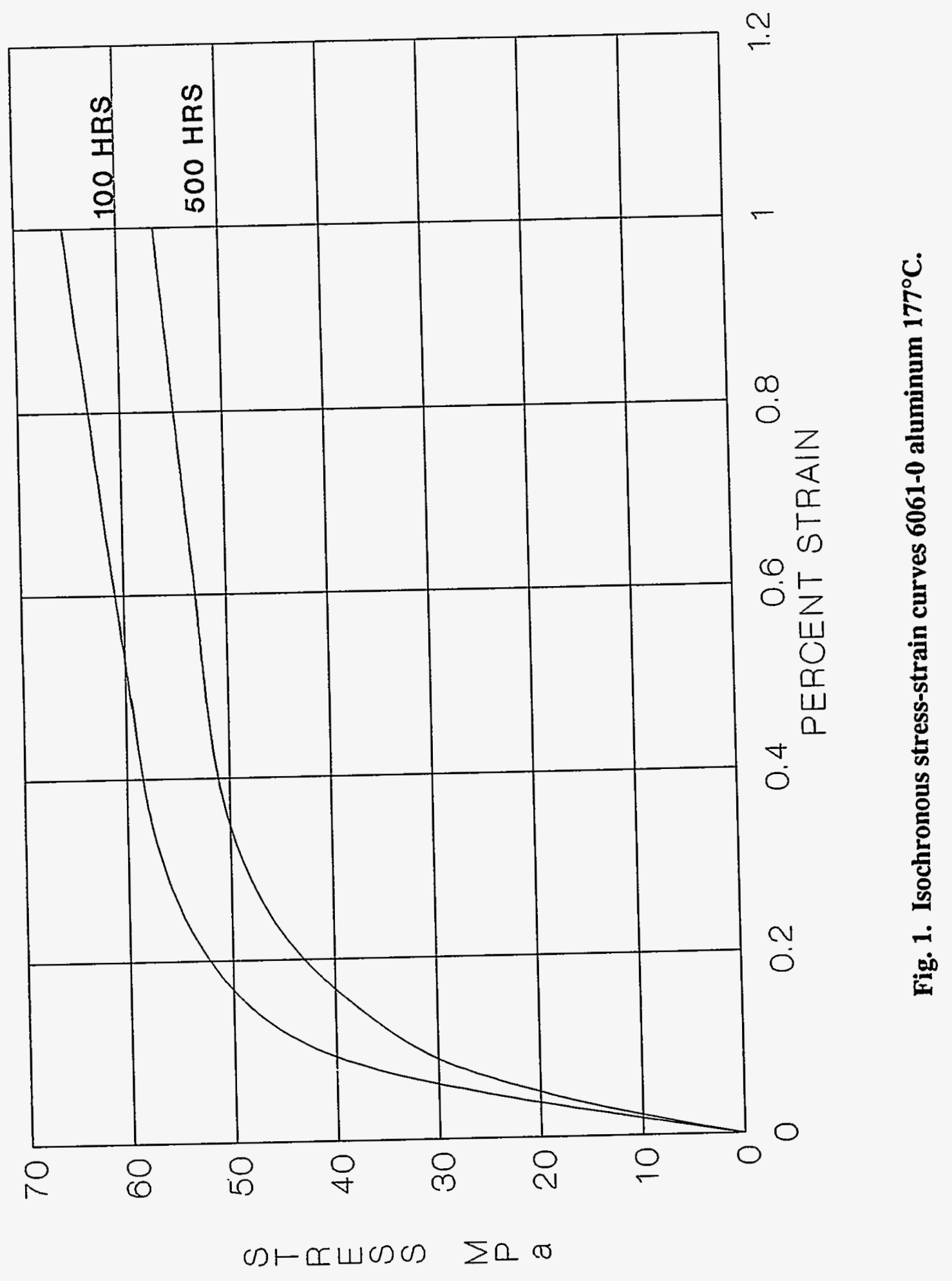




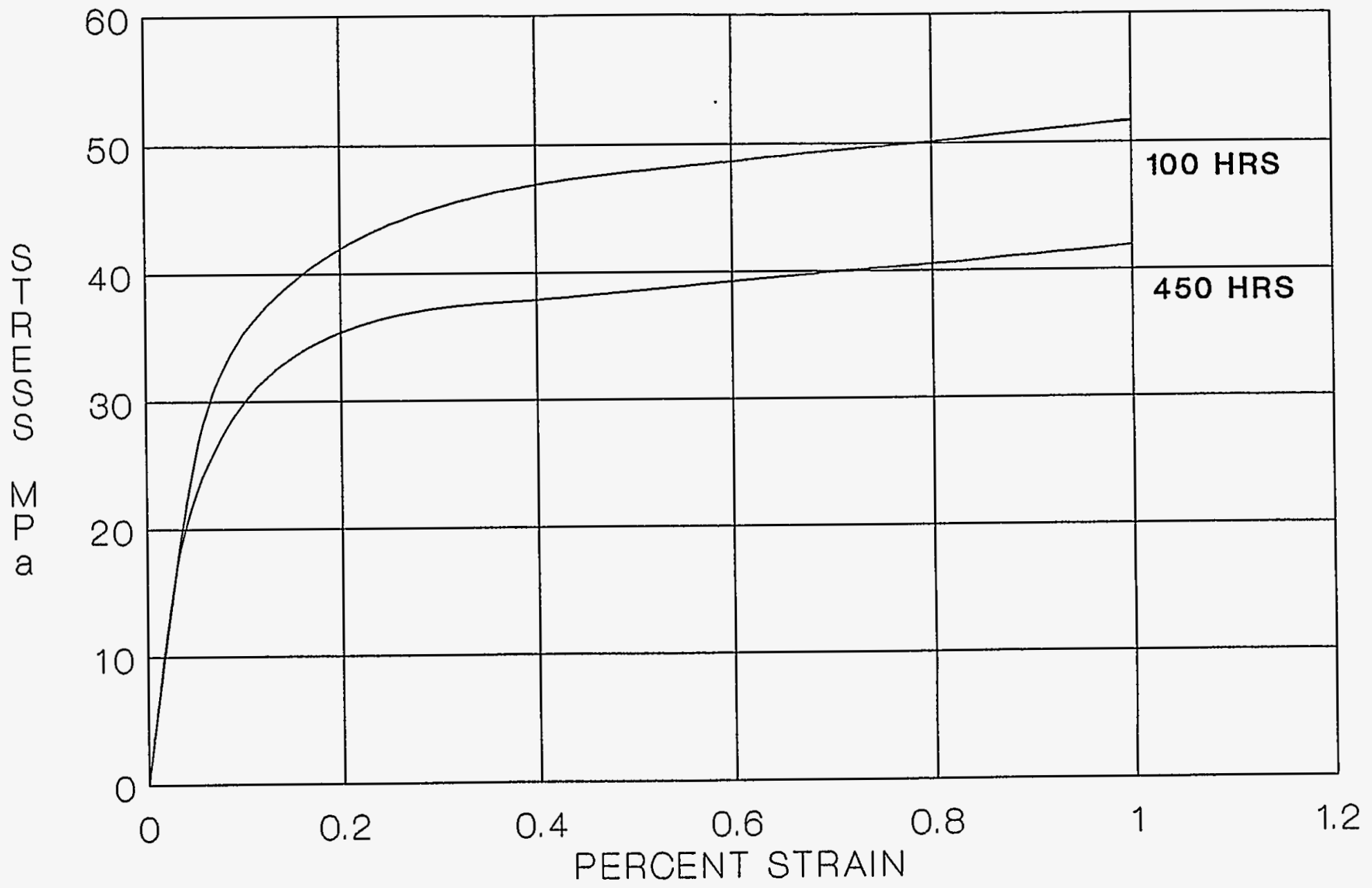

u

Fig. 2. Isochronous stress-strain curves $6061-0$ aluminum $204^{\circ} \mathrm{C}$. 


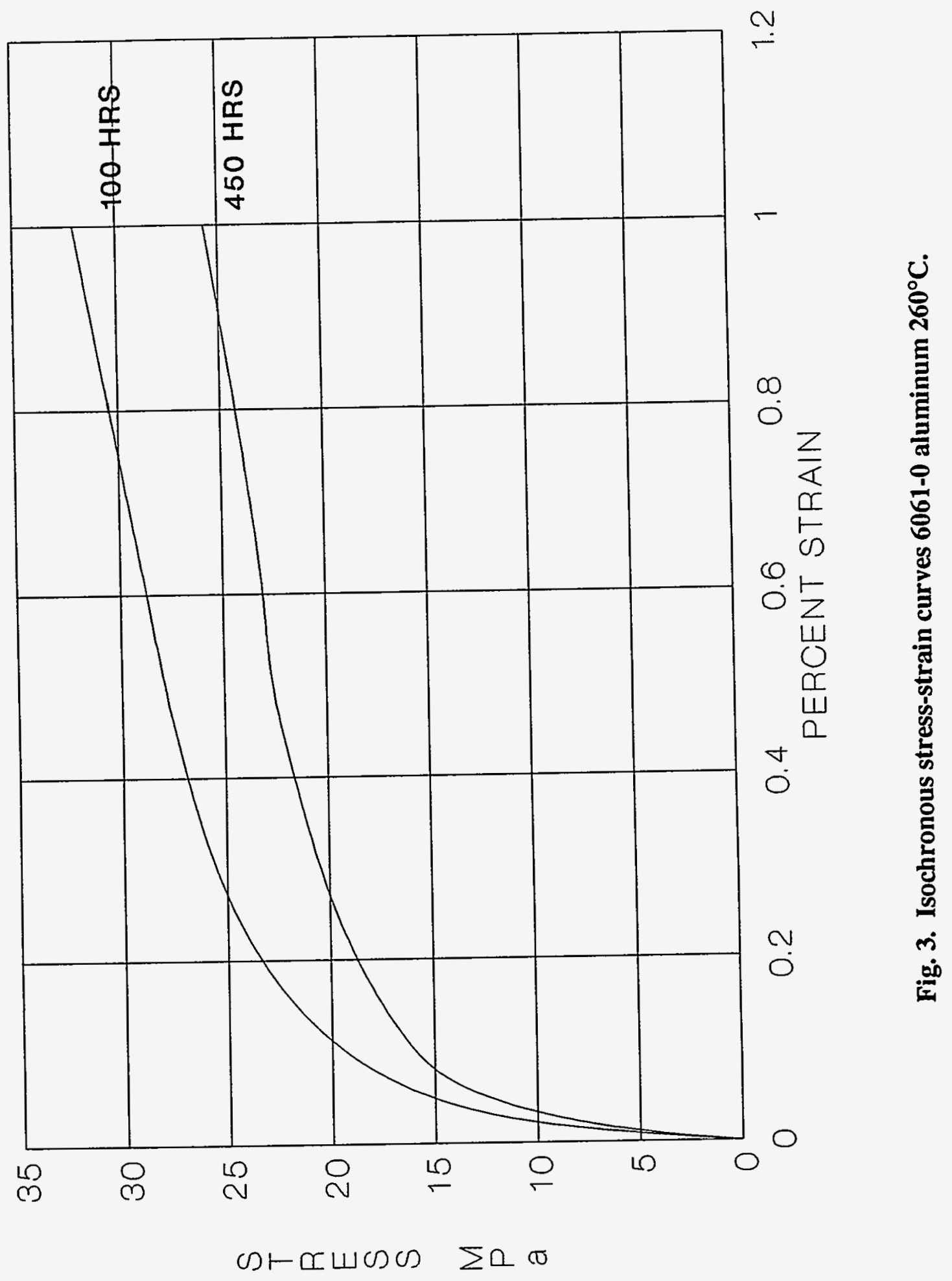


the stress, strain, and deformation in the structure. The difference in the deformation solutions represents the creep in the structure.

In determining the calibration constants of Eq. (2), if data are selected near the expected maximum stress level for the calculations, the results will be more representative of the deformation that can be anticipated in the prototype. Some experience in determining the calibration constants is helpful. For example, within a given range, the experimental data can appear to be matched rather well, as illustrated in Fig. 4. The difficulty with the match of Fig. 4 is the initial slope, which is twice the room temperature modulus for aluminum and, therefore, unrealistic. Smith and Sidebottom ${ }^{3}$ recommended finding the constants by taking the initial slope of the experimental curves shown in Figs. 1-3 and selecting a stress level through which the fitted curve passes. The stress level, $\sigma_{d}$, is picked to represent the maximum stress level expected in a given calculation. The results of evaluating constants in this way are illustrated in Fig. 5. The curve fit does not appear as close as the fit in Fig. 4, but experience shows that resulting calculations are more representative of the creep involved. Table 1 gives constants that are calculated using the initial slope of the stress-strain curve and a particular stress level, $\sigma_{d}$. Because many solutions are based on equilibrium (stress), it appears that when the fitted curve is below the actual curve, larger strains will be calculated, and for a fitted curve above the actual curve, smaller strains will be calculated. From this perspective, when larger strains are calculated, there will be some safety margin in the results. 


\section{APPROXIMATION I FITS THE DATA TO THE}

INITIAL SLOPE AND ONE STRESS VALUE

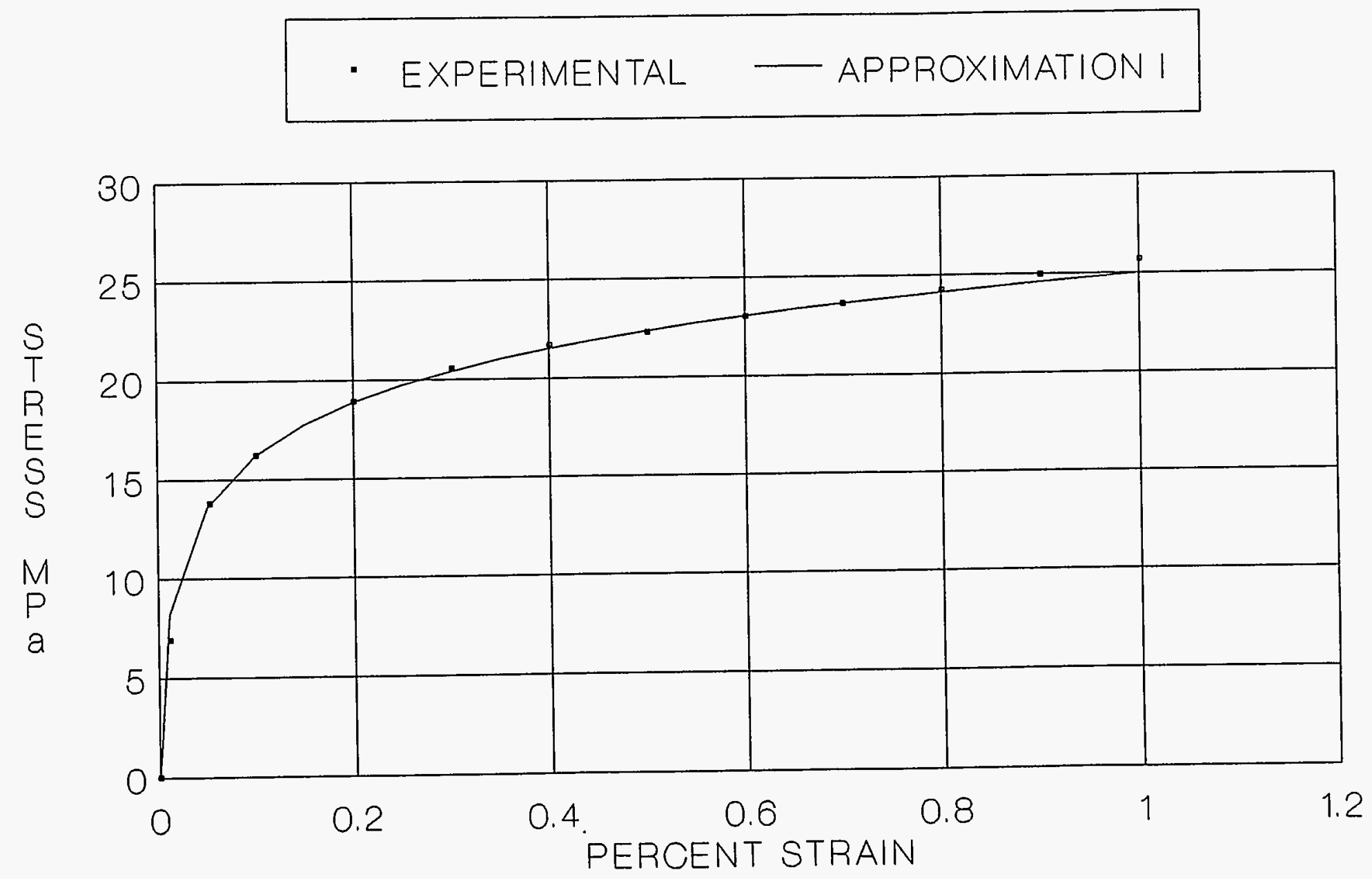

Fig. 4. Isochronous data approximation I $6061-0$ aluminum $260^{\circ} \mathrm{C}$ and 450 hours. 


\section{APPROXIMATION II FITS THE DATA TO THE INITIAL SLOPE AND ONE STRESS VALUE}

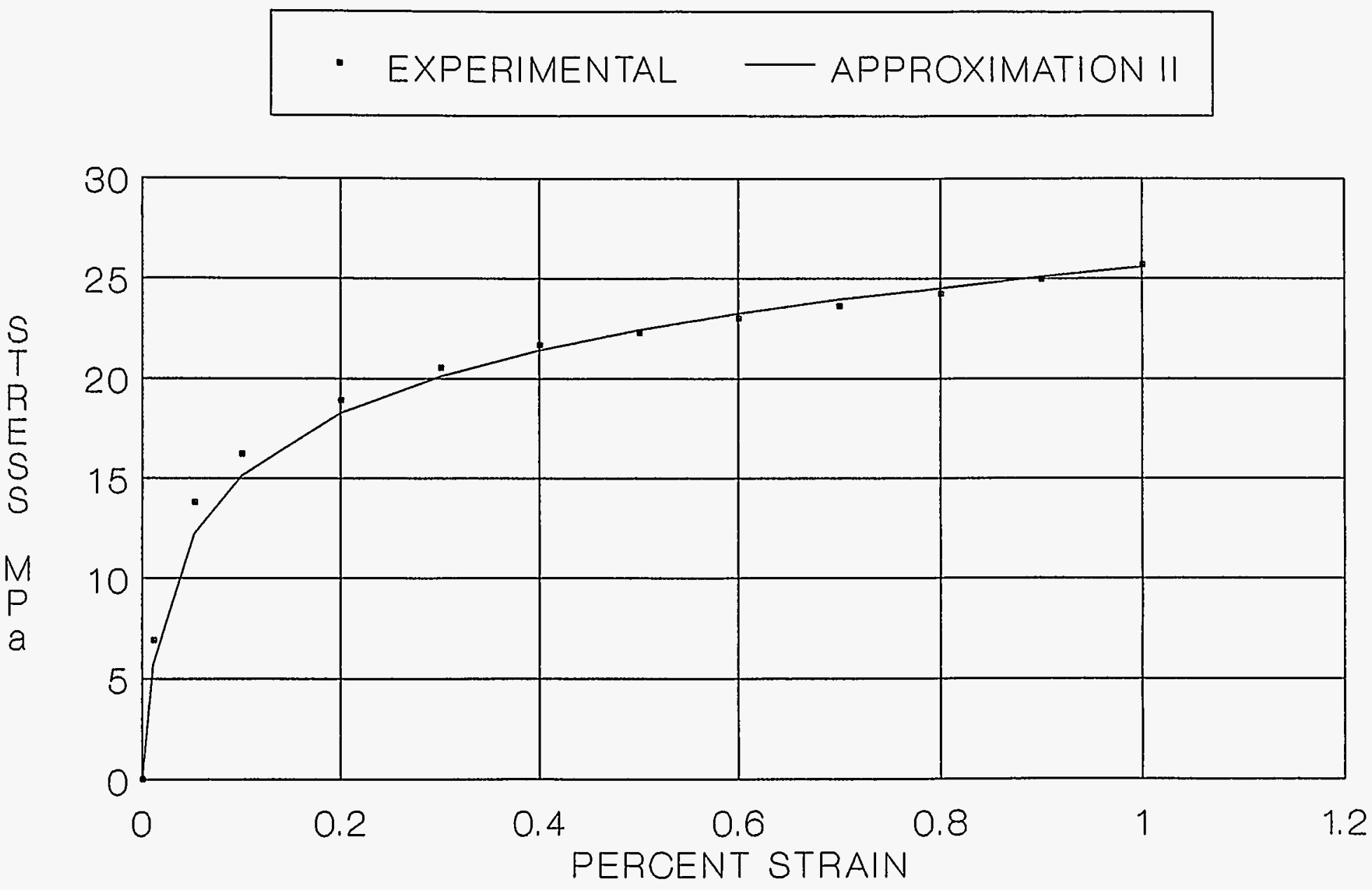

Fig. 5. Isochronous data approximation II $6061-0$ aluminum $260^{\circ} \mathrm{C}$ and 450 hours. 
Table 1. Calculated constants

\begin{tabular}{|c|c|c|c|c|c|c|c|}
\hline $\begin{array}{c}\text { Time } \\
\text { (h) }\end{array}$ & $\begin{array}{l}\text { Temp. } \\
\left({ }^{\circ} \mathrm{C}\right)\end{array}$ & $\begin{array}{c}\text { Temp. } \\
\left({ }^{\circ} \mathrm{F}\right)\end{array}$ & $\begin{array}{c}\sigma_{o} \\
(\mathrm{MPa})\end{array}$ & $\begin{array}{c}\sigma_{o} \\
(\mathrm{psi})\end{array}$ & $\begin{array}{c}\varepsilon_{o} \\
\text { (micro-strain) }\end{array}$ & $\begin{array}{c}\sigma_{d} \\
(\mathrm{MPa})\end{array}$ & $\begin{array}{c}\sigma_{d} \\
(\mathrm{psi})\end{array}$ \\
\hline \multirow[t]{4}{*}{100} & 177 & 350 & 29.60 & 4294 & 506 & 42.75 & 6200 \\
\hline & & & 25.01 & 3627 & 427 & 51.02 & 7400 \\
\hline & & & 21.78 & 3072 & 362 & 55.16 & 8000 \\
\hline & & & 15.00 & 2175 & 256 & 65.50 & 9500 \\
\hline \multirow[t]{4}{*}{500} & & & 17.03 & 2470 & 291 & 34.47 & 5000 \\
\hline & & & 16.74 & 2428 & 286 & 41.37 & 6000 \\
\hline & & & 15.78 & 2289 & 270 & 48.95 & 7100 \\
\hline & & & 12.82 & 1860 & 219 & 55.16 & 8000 \\
\hline \multirow[t]{4}{*}{100} & 204 & 400 & 28.40 & 4119 & 480 & 36.54 & 5300 \\
\hline & & & 16.33 & 2368 & 276 & 41.37 & 6000 \\
\hline & & & 14.12 & 2048 & 239 & 45.50 & 6600 \\
\hline & & & 12.35 & 1792 & 209 & 48.26 & 7000 \\
\hline \multirow[t]{3}{*}{450} & & & 20.10 & 2916 & 340 & 27.58 & 4000 \\
\hline & & & 12.84 & 1863 & 217 & 34.47 & 5000 \\
\hline & & & 8.63 & 1252 & 146 & 41.37 & 6000 \\
\hline \multirow[t]{3}{*}{100} & 260 & 500 & 6.77 & 982 & 107 & 20.68 & 3000 \\
\hline & & & 6.08 & 882 & 96 & 27.58 & 4000 \\
\hline & & & 6.00 & 870 & 95 & 32.40 & 4700 \\
\hline \multirow[t]{3}{*}{450} & & & 4.99 & 724 & 79 & 15.86 & 2300 \\
\hline & & & 4.67 & 677 & 74 & 20.68 & 3000 \\
\hline & & & 4.55 & 660 & 72 & 25.51 & 3700 \\
\hline
\end{tabular}




\section{CREEP SOLUTION SCHEME}

The scheme for obtaining a solution using the load from Eq. (1) and the stress-strain relation of Eq. (2) is based on complementary energy techniques or

$$
\delta_{i}=\frac{\partial \gamma}{\partial F_{i}}
$$

where

$\gamma=$ complementary energy in a structure,

$\delta_{i}=$ deflection at a point on the structure and in the direction of an applied force, $F_{i}$, at that point, and

$$
\Delta \Theta_{i}=\frac{\partial \gamma}{\partial M_{i}}
$$

where $\Delta \Theta_{i}=$ rotation at a point on the structure and in the same sense as an applied moment, $M_{i}$, at that point.

For deformation from bending, the usual assumption is to have cross-sectional planes remain plane during bending (Fig. 6) or

$$
\varepsilon=\frac{y}{\rho},
$$

where $\rho$ is the radius of curvature because of deformation and $y$ is the distance from neutral axis to the point in question. Equilibrium requires

$$
M=\int_{A} \sigma y d A,
$$




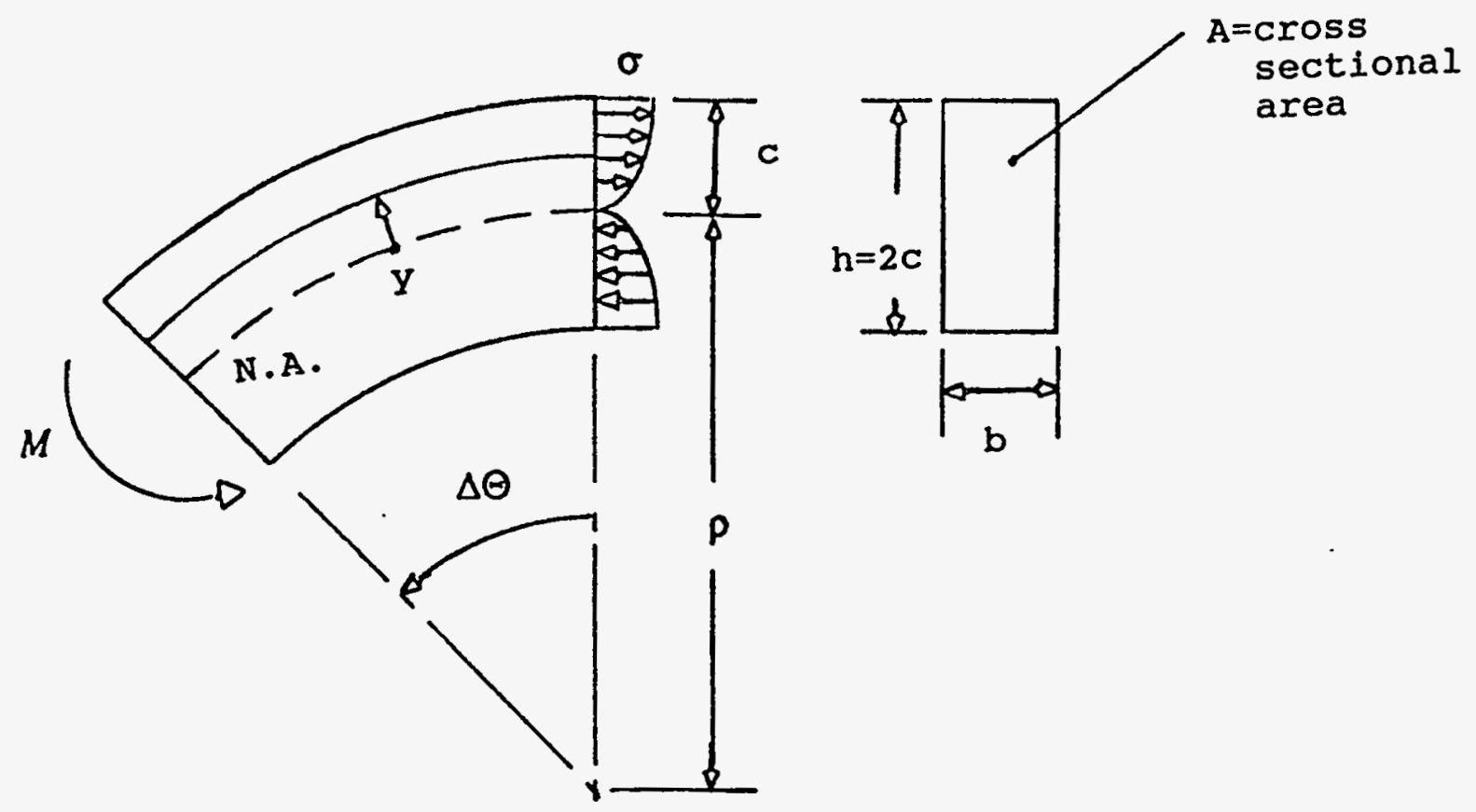

Fig. 6. Beam element. 
where

$$
\begin{aligned}
M & =\text { moment } \\
A & =\text { cross-sectional area } \\
d A & =\text { element of cross-sectional area. }
\end{aligned}
$$

Expanding Eq. (6) with Eq. (2) and integrating,

$$
M=\frac{b \sigma_{o}}{2}\left\{\left(\varepsilon_{o} \rho\right)^{2}\left[2\left(\frac{c}{\varepsilon_{o} \rho}\right)^{2}+1\right] \operatorname{arcsinh}\left(\frac{c}{\rho \varepsilon_{o}}\right)-c \varepsilon_{o} \rho \sqrt{\left(\frac{c}{\varepsilon_{o} \rho}\right)^{2}+1}\right\},
$$

where

$b=$ width of beam model,

$c=$ half of the height of beam model.

For later discussion, it is convenient here to note that the curvature is a function of the moment or

$$
\frac{1}{\rho}=f(M)
$$

where the function, $f(M)$, is related through Eq. (7) to the curvature, $\frac{1}{\rho}$.

For a beam in bending by moment, Eqs. (3) and (4) can be expressed as

$$
\delta_{i}=\int_{0}^{\phi_{\ell}} \frac{1}{\rho} \frac{\partial M}{\partial F_{i}} \phi a d \phi=\int_{0}^{\phi_{\ell}} f(M) \frac{\partial M}{\partial F_{i}} \phi a d \phi
$$

and 


$$
\Delta \Theta_{i}=\int_{o}^{\phi_{l}} \frac{1}{\rho} \frac{\partial M}{\partial M_{i}} \phi a d \phi=\int_{0}^{\phi_{\ell}} f(M) \frac{\partial M}{\partial M_{i}} \phi a d \phi,
$$

where

$$
\begin{aligned}
a & =\text { inner support radius for the involute } \\
d \phi & =\text { element of involute angle, } \\
\phi & =\text { involute angle } \\
\phi_{\ell} & =\text { total involute angle. }
\end{aligned}
$$

The rationale in going from Eqs. (3) and (4) to Eqs. (9) and (10) is given in Appendix A.

The complementary energy, resulting from the so-called axial load ( $N$ of Fig. 7 ) that lies in the plane of the plate's involute arc and causes uniform compression or tension, was examined with a numerical approximation. The results of the numerical calculations indicated that the contribution to the complementary energy from the axial load, $N$, in comparison to the bending load, $M$, was very small and is neglected in the following analysis.

Referencing the notation of Fig. 7, the equations of an involute are

$$
\begin{aligned}
a \phi & =\left(r^{2}-a^{2}\right)^{1 / 2} \\
d s & =a \phi d \phi \\
x & =a(s \phi-\phi c \phi) \\
y & =a(c \phi+\phi s \phi-1),
\end{aligned}
$$

where

$$
\begin{aligned}
r & =\text { radius to any point on the involute, } \\
d s & =\text { element of arc length } \\
x & =\text { involute coordinate, } \\
s \phi & =\text { sine } \phi \\
c \phi & =\text { cosine } \phi, \\
y & =\text { involute coordinate. }
\end{aligned}
$$


The values of $V_{o p}, M_{o p}$, and $N_{o p}$ can be found using Castigliano's complementary energy theorems, Eqs. (9) and (10). The moment and associated derivatives at any section of the involute can be expressed from equilibrium as

$$
\begin{gathered}
M=M_{o p}+N_{o p} a(s \phi-\phi c \phi)+V_{o p} a(1-c \phi-\phi s \phi)+p a^{2}\left(1+\frac{\phi^{2}}{2}-c \phi-\phi s \phi\right) \\
\frac{\partial M}{\partial M_{o p}}=1 \quad \frac{\partial M}{\partial N_{o p}}=a(s \phi-\phi c \phi) \quad \frac{\partial M}{\partial V_{o p}}=a(I-c \phi-\phi s \phi),
\end{gathered}
$$

where

$M_{o p}=$ moment applied to involute from inside boundary,

$N_{o p}=$ force applied to involute from inside boundary,

$V_{o p}=$ shear load applied to involute from inside boundary,

$p=$ pressure load applied to plate.

Boundary conditions at the inside involute support require

$$
\begin{gathered}
o=\int_{o}^{\phi_{\ell}} f(M) \frac{\partial M}{\partial N_{o p}} \phi a d \phi \quad o=\int_{o}^{\phi_{\ell}} f(M) \frac{\partial M}{\partial V_{o p}} \phi a d \phi \\
o=\int_{o}^{\phi_{\ell}} f(M) \frac{\partial M}{\partial M_{o p}} \phi a d \phi .
\end{gathered}
$$

By solving Eqs. (13) simultaneously, values for $M_{o p}, V_{o p}$, and $N_{o p}$ can be found. The function, $f(M)$, is not expressible in explicit form and therefore Eqs. (13) are solved numerically. The involute is considered to be made up of " $n$ " straight beam segments. For each segment, " $i$ " found in the $n$ segments (or elements), the boundary loads $M_{o p}, N_{o p}$, and $V_{o p}$ are related to the deformed radius of curvature, $\rho_{i}$, through Eqs. (7) and (12) as 


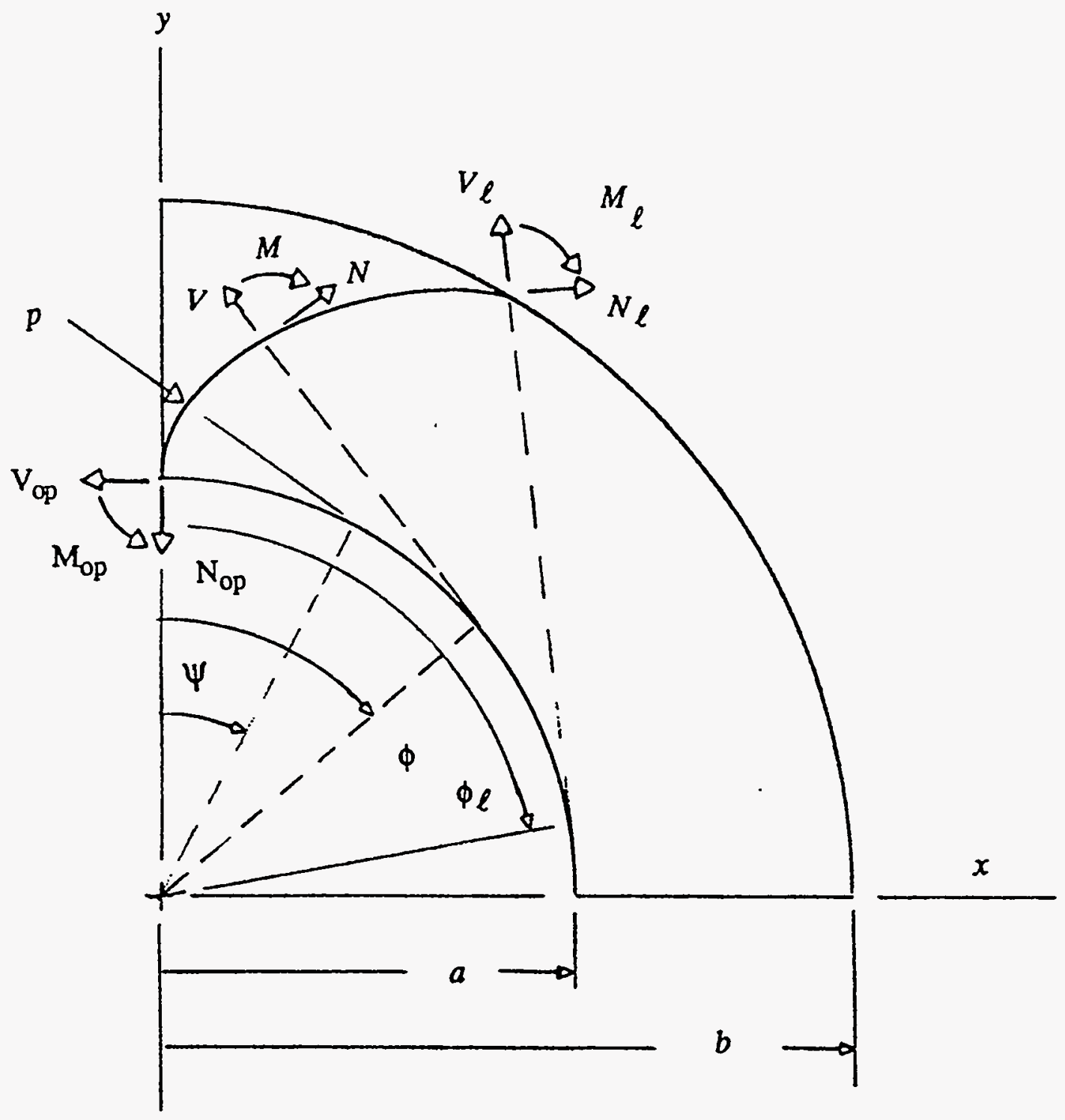

Fig. 7. Involute forces and geometry. 


$$
\begin{aligned}
& M_{o p}+N_{o p} a\left(s \phi_{i}-\phi_{i} c \phi_{i}\right)+V_{o p} a\left(1-c \phi_{i}-\phi_{i} s \phi_{i}\right)+p a^{2}\left(1+\frac{\phi_{i}^{2}}{2}-c \phi_{i}-\phi_{i} s \phi_{i}\right) \\
& =\frac{b \sigma_{o}}{2}\left\{\left(\varepsilon_{o} \rho_{i}\right)^{2}\left[2\left(\frac{c}{\varepsilon_{o} \rho_{i}}\right)^{2}+1\right] \operatorname{arcsinh}\left(\frac{c}{\rho_{i} \varepsilon_{o}}\right)-c \varepsilon_{o} \rho_{i} \sqrt{\left(\frac{c}{\varepsilon_{o} \rho_{i}}\right)^{2}+1}\right\},
\end{aligned}
$$

where $\phi_{i}=$ involute angle to segment " $i$ ", giving $n$ equations with $n+3$ unknowns, $\left(M_{o p}, N_{o p}, V_{o p}, \rho_{1}, \rho_{2}, \ldots, \rho_{n}\right)$.

The integrals of Eqs. (13) are approximated as

$$
\begin{gathered}
o=\int_{0}^{\phi_{\ell}} \frac{1}{\rho} \frac{\partial M}{\partial M_{o p}} \phi a d \phi \approx \sum_{1}^{n} \frac{1}{\rho_{i}}(1) \Delta s_{i} \quad o=\int_{o}^{\phi_{l}} \frac{1}{\rho} \frac{\partial M}{\partial N_{o p}} \phi a d \phi \approx \sum_{1}^{n} \frac{1}{\rho_{i}} a\left(s \phi_{i}-\phi_{i} c \phi_{i}\right) \Delta s_{i} \\
o=\int_{o}^{\phi_{\ell}} \frac{1}{\rho} \frac{\partial M}{\partial V_{o p}} \phi a d \phi \approx \sum_{1}^{n} \frac{1}{\rho_{i}} a\left(1-c \phi_{i}-\phi_{i} s \phi_{i}\right) \Delta s_{i}
\end{gathered}
$$

where $\Delta s_{i}$ is the element length. Equations (15) yield three more equations and no more unknowns; thus, Eqs. (14) and (15) form a complete set for determining the unknowns, $\left(M_{o p}, N_{o p}, V_{o p}, \rho_{1}, \rho_{2}, \ldots, \rho_{n}\right)$.

The deflection of one end of a straight beam segment relative to the other end can be expressed in terms of its deformed radius of curvature (Fig. 8) as

$$
\Delta_{i}=\rho_{i}\left(1-\cos \frac{\Delta s_{i}}{\rho_{\mathrm{i}}}\right)+\Delta s_{i} \sin \left(\frac{\Delta s_{1}}{\rho_{1}} \cdots+\frac{\Delta s_{i-1}}{\rho_{i-1}}+\frac{\Delta s_{i}}{\rho_{i}}\right),
$$




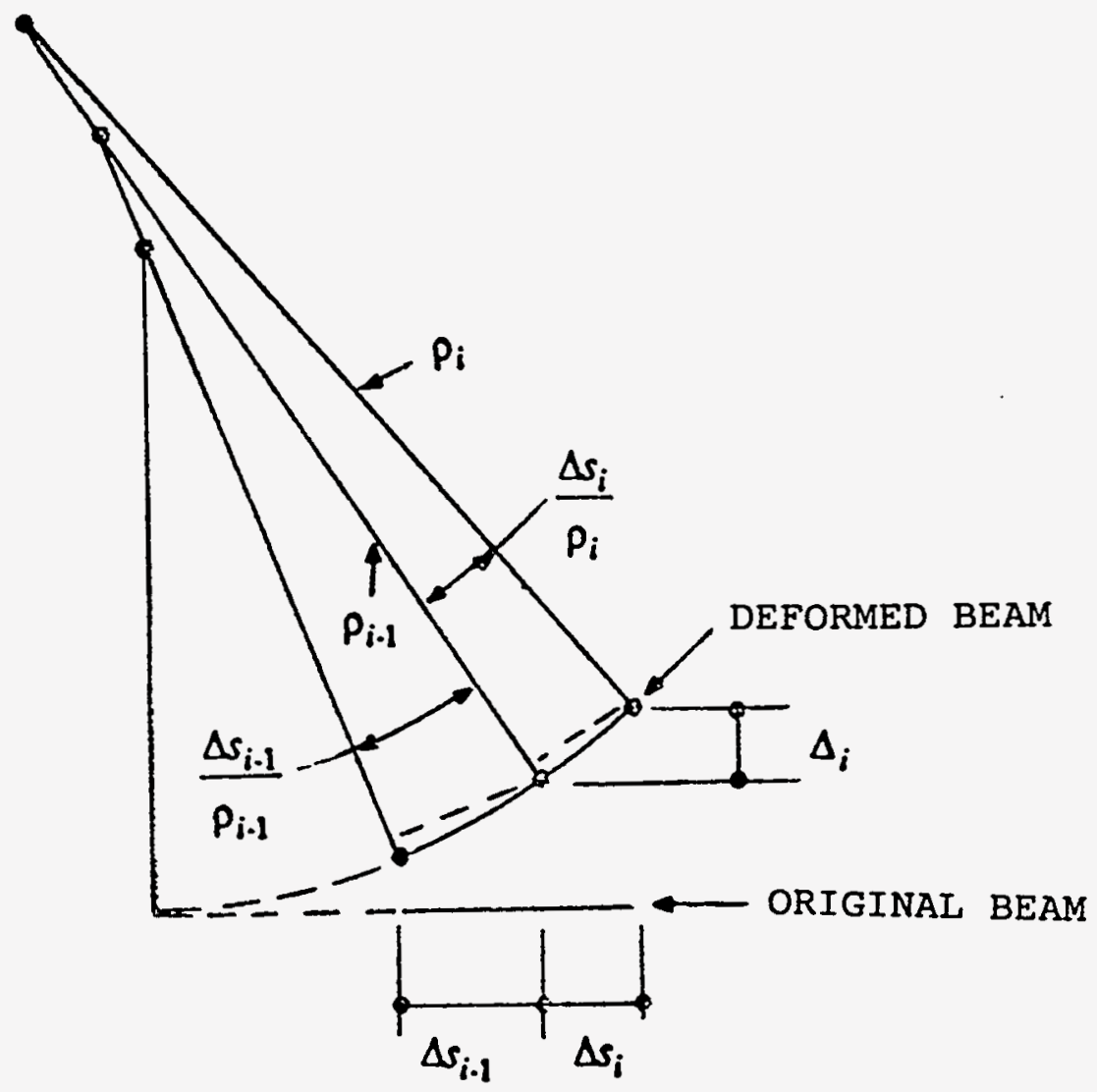

Fig. 8. Beam element deformation. 
where

$\Delta_{i}=$ deflection of one end of a straight beam segment relative to the other end, $\Delta s_{i}=$ element length at point " $i$ ".

Hence, the deflection $\delta_{j}$, at some point " $j$ " relative to its original location, can be approximated as

$$
\delta_{j}=\Delta_{1}+\Delta_{2}+\cdots+\Delta_{j}
$$

where

$\delta_{j}=$ deflection at point " $\vec{\jmath}$ ",

$\Delta_{1}=$ deflection of one end of beam segment 1 relative to the other,

$\Delta_{2}=$ deflection of one end of beam segment 2 relative to the other.

Table 2 is a tabulation of the resulting maximum deflection because of the pressure load with creep included for different times and temperatures. The average temperature for the upper plate is projected to be $191^{\circ} \mathrm{C}$. At this temperature, the maximum deflection from creep is calculated to be $6 \%$ of the channel width. The average temperature for the lower plate is projected to be $140^{\circ} \mathrm{C}$. At this temperature, the maximum deflection from creep is calculated to be less than $6 \%$ of the channel width. It is also noted that, in some instances, the deflection with creep calculates to be less than the elastic deflection. This is a reflection of the different analytical models used that have different stress distributions at any given cross section.

There is deflection because of the thermal effect of the plates being hotter than the side supports. It is reasoned that all plates undergo the same deflection resulting from the thermal load and, therefore, the channel openings remain essentially constant. The result of this reasoning has the plate deflection from the pressure load (flow load) as being the only deformation that might significantly change the flow channel area. 
Table 2. Maximum involute plate deflection

The flow velocity is taken as $25 \mathrm{~m} / \mathrm{s}$ ( $82.02 \mathrm{fps}$ ) with the pressure deferential across a plate experimentally determined as $0.1558 \mathrm{MPa}$ (22.6 psi).

\begin{tabular}{lccccc}
\hline & \multicolumn{2}{c}{ Upper plate } & & \multicolumn{2}{c}{ Lower plate } \\
\cline { 2 - 3 } \cline { 6 - 6 } & $\mathrm{mm}$ & in. & & $\mathrm{mm}$ & in. \\
\hline Room temperature (elastic analysis) & 0.05 & 0.002 & & 0.09 & 0.003 \\
$100 \mathrm{~h}$ at $177^{\circ} \mathrm{C}\left(350^{\circ} \mathrm{F}\right)$ & 0.06 & 0.002 & & 0.07 & 0.003 \\
$500 \mathrm{~h}$ at $177^{\circ} \mathrm{C}\left(350^{\circ} \mathrm{F}\right)$ & 0.06 & 0.002 & 0.08 & 0.003 \\
$100 \mathrm{~h}$ at $204^{\circ} \mathrm{C}\left(400^{\circ} \mathrm{F}\right)$ & 0.06 & 0.002 & 0.08 & 0.003 \\
$450 \mathrm{~h}$ at $204^{\circ} \mathrm{C}\left(400^{\circ} \mathrm{F}\right)$ & 0.07 & 0.003 & & 0.12 & 0.005 \\
$100 \mathrm{~h}$ at $260^{\circ} \mathrm{C}\left(500^{\circ} \mathrm{F}\right)$ & 0.04 & 0.002 & & 0.19 & 0.007 \\
$450 \mathrm{~h}$ at $260^{\circ} \mathrm{C}\left(500^{\circ} \mathrm{F}\right)$ & 0.06 & 0.002 & 0.37 & 0.014 \\
\hline
\end{tabular}




\section{STRESS ANALYSIS WITH THE CREEP MODEL}

In the elastic analysis of the plates, ${ }^{1}$ the stresses were not small and represented more of a design limit than did the deformation. With creep analyses, there is some reduction in the resulting stresses, and this is beneficial in the reactor design. An analysis of these stresses using a creep model is given in the following sections.

The stresses in the direction of the involute arc (called the transverse direction) reacting to the pressure caused by flow are primarily bending stresses. The largest stresses are found where the plates intersect the inside support boundary and where the involute angle is zero. Values for the boundary loads, $M_{o p}$ and $N_{o p}$, were calculated, as noted above, through Eqs. (13). The normal strain necessary to support the boundary moment, $M_{o p}$, can be determined with Eqs. (5) and (7). The strain needed to support the boundary axial load, $N$, is

$$
\varepsilon_{N o p}=\varepsilon_{o} \sinh \left(\frac{N_{o p}}{\sigma_{o} 2 c}\right)
$$

where $\varepsilon_{N o p}=$ strain caused by the boundary load, $N_{o p}$.

Superimposing these two strains (i.e., the strains caused by $M_{o p}$ and $N_{o p}$ ), the peak boundary stresses in the transverse sense can be evaluated from

$$
\sigma=\sigma_{o} \operatorname{arcsinh}\left(\frac{ \pm c}{\rho \varepsilon_{o}}+\frac{\varepsilon_{\text {Nop }}}{\varepsilon_{o}}\right)
$$

Calculated stress levels are given in Table 3. With only the pressure load applied, all of the stresses calculated were less than $73 \%$ of the ultimate tensile stress.

In addition to the moment caused by the pressure load on the plates, there is a moment exerted by the thermal expansion of the plate being more than the expansion of the side supports. The moment because of thermal expansions is minimized by allowing one of the support cylinders to be free of a rotational constraint. Also, it should be noted that this moment will diminish with increased time at elevated temperatures because of creep. For the purpose of analysis, the plate is first allowed to expand in the direction of $N_{o p}$ by 
Table 3. Transverse plate stresses resulting from pressure [flow velocity $=25 \mathrm{~m} / \mathrm{s}(82 \mathrm{fps})$; plate pressure differential $=0.1558 \mathrm{MPa}(22.6 \mathrm{psi})]$

\begin{tabular}{|c|c|c|c|c|c|}
\hline & \multirow{2}{*}{$\begin{array}{c}\text { Maximum } \\
\text { normal strain }\end{array}$} & \multicolumn{2}{|c|}{$\begin{array}{c}\text { Maximum normal } \\
\text { stress in plate }\end{array}$} & \multicolumn{2}{|c|}{$\begin{array}{l}\text { Ultimate tensile } \\
\text { stress (ref. 1) }\end{array}$} \\
\hline & & (MPa) & (psi) & $(\mathrm{MPa})$ & (psi) \\
\hline \multicolumn{6}{|c|}{ Lower plate } \\
\hline \multicolumn{6}{|l|}{ Room temperature } \\
\hline (elastic analysis) & 0.00106 & 73.1 & 10600 & 135.4 & 19600 \\
\hline $100 \mathrm{~h}$ at $177^{\circ} \mathrm{C}\left(350^{\circ} \mathrm{F}\right)$ & 0.00367 & 63.8 & 9250 & 118.4 & 17200 \\
\hline $500 \mathrm{~h}$ at $177^{\circ} \mathrm{C}\left(350^{\circ} \mathrm{F}\right)$ & 0.00483 & 56.4 & 8190 & 118.4 & 17200 \\
\hline $100 \mathrm{~h}$ at $204^{\circ} \mathrm{C}\left(400^{\circ} \mathrm{F}\right)$ & 0.00560 & 54.4 & 7880 & 106.4 & 15400 \\
\hline $450 \mathrm{~h}$ at $204^{\circ} \mathrm{C}\left(400^{\circ} \mathrm{F}\right)$ & 0.01202 & 44.1 & 6390 & 106.4 & 15400 \\
\hline $100 \mathrm{~h}$ at $260^{\circ} \mathrm{C}\left(500^{\circ} \mathrm{F}\right)$ & 0.02768 & 38.2 & 5540 & 52.1 & 7550 \\
\hline $450 \mathrm{~h}$ at $260^{\circ} \mathrm{C}\left(500^{\circ} \mathrm{F}\right)$ & 0.07128 & 34.5 & 5010 & 52.1 & 7550 \\
\hline \multicolumn{6}{|c|}{ Upper plate } \\
\hline \multicolumn{6}{|l|}{ Room temperature } \\
\hline (elastic analysis) & 0.00065 & 44.8 & 6500 & 135.4 & 19600 \\
\hline $100 \mathrm{~h}$ at $177^{\circ} \mathrm{C}\left(350^{\circ} \mathrm{F}\right)$ & 0.00157 & 50.4 & 7310 & 118.4 & 17200 \\
\hline $500 \mathrm{~h}$ at $177^{\circ} \mathrm{C}\left(350^{\circ} \mathrm{F}\right)$ & 0.00176 & 42.1 & 6110 & 118.4 & 17200 \\
\hline $100 \mathrm{~h}$ at $204^{\circ} \mathrm{C}\left(400^{\circ} \mathrm{F}\right)$ & 0.00176 & 41.7 & 6040 & 106.4 & 15400 \\
\hline $450 \mathrm{~h}$ at $204^{\circ} \mathrm{C}\left(400^{\circ} \mathrm{F}\right)$ & 0.00207 & 37.9 & 5500 & 106.4 & 15400 \\
\hline $100 \mathrm{~h}$ at $260^{\circ} \mathrm{C}\left(500^{\circ} \mathrm{F}\right)$ & 0.00629 & 29.6 & 4300 & 52.1 & 7550 \\
\hline $450 \mathrm{~h}$ at $260^{\circ} \mathrm{C}\left(500^{\circ} \mathrm{F}\right)$ & 0.01175 & 26.3 & 3820 & 52.1 & 7550 \\
\hline
\end{tabular}




$$
\alpha y_{\ell} \Delta T
$$

where

$$
\begin{aligned}
\alpha & =\text { coefficient of thermal expansion, } \\
y_{\ell} & =\text { the y-coordinate projection of the plate } \\
\Delta T & =\text { the average temperature difference between the plate and side walls. }
\end{aligned}
$$

Next, the expansion deflection is removed by applying a force $N_{o p}$, which is expressed in complementary energy terms as

$$
\frac{\partial \gamma}{\partial N_{o p}}=-\alpha y_{\ell} \Delta T=\int_{o}^{\phi \ell} f(M) \frac{\partial M}{\partial N_{o p}} a \phi d \phi
$$

The plate displacement in the direction that is tangent to the support cylinders (direction of $V_{o p}$ ) can be expressed in terms of rotation, $(a) \frac{\partial \gamma}{\partial M_{o p}}$, or displacement, $\frac{\partial \gamma}{\partial V_{o p}}$; thus,

$$
-a \int_{o}^{\phi \ell} f(M) \frac{\partial M}{\partial M_{o p}} a \phi d \phi=\int_{o}^{\phi \ell} f(M) \frac{\partial M}{\partial V_{o p}} a \phi d \phi
$$

From equilibrium of the inner support, which is assumed free to rotate, the moment $\left(V_{o p} a\right)$ balances $M_{o p}$ or

$$
V_{o p} a=-M_{o p}
$$

Eqs. (21-23) can be solved for the boundary loads. A conservative estimate of the total boundary load caused by the flow induced pressure and the thermal expansion of the plates is found by superimposing these two boundary loads. The estimate is conservative because the boundary load caused by the thermal expansion of the plates relaxes some in time because of 
creep. The stresses from these combined loads are tabulated in Table 4. For this combined loading, the calculated stresses were all less than $83 \%$ of the reported ultimate tensile stress. An elastic analysis of the plates for these loads had calculated stresses above the yield stress property as given at room temperature; thus, creep is beneficial in this respect.

The longitudinal stresses (stresses parallel to the flow direction) are evaluated as follows. Referencing Fig. 9, equilibrium requires

$$
F_{p s}+F_{o}+F_{i}=0
$$

where

$$
\begin{aligned}
& F_{p s}=\text { average force in the plates in the longitudinal direction, } \\
& F_{o}=\text { average force in the outside support cylinder in the longitudinal direction, } \\
& F_{i}=\text { average force in the inside support cylinder in the longitudinal direction. }
\end{aligned}
$$

Geometry requires

$$
\delta_{p s}=\delta_{o}=\delta_{i}
$$

where

$$
\begin{aligned}
\delta_{p s} & =\text { average longitudinal displacement of the plates, } \\
\delta_{o} & =\text { average longitudinal displacement of the outside support, } \\
\delta_{i} & =\text { average longitudinal displacement of the inside support. }
\end{aligned}
$$

Treating the side supports as elastic members (because of the relatively low temperatures) and using Eq. (24), Eq. (25) can be reduced to

$$
\varepsilon_{p s}=-\frac{\sigma_{p s} A_{p s}}{A_{o} E_{o}\left(1+\frac{A_{i}}{A_{o}}\right)}+\alpha\left(T_{o}-T_{p s}\right)
$$


where

$$
\begin{aligned}
E_{o}= & \text { room temperature modulus of elasticity, } \\
\varepsilon_{p s}= & \text { the average normal strain in the plates, } \\
\sigma_{p s}= & \text { the average normal stress in the plates, } \\
A_{p s}, A_{o}, A_{i}= & \text { cross-sectional areas of plates, outside support, and inside support, } \\
& \text { respectively, } \\
T_{o}, T_{p s}= & \text { support temperature and plate temperature. }
\end{aligned}
$$

Equation (26) can be solved by trial and error using Figs. 1-3. The results are tabulated in Table 5. All of the calculated stresses were less than $55 \%$ of the ultimate tensile stress property. An elastic analysis using room temperature plate properties had calculated stresses well into the yield stress range and, again, creep is beneficial. 
Table 4. Maximum transverse stress from combined pressure and thermal load [pressure load $=0.1558 \mathrm{MPa}(22.6 \mathrm{psi})$; boundary temperatures $=52^{\circ} \mathrm{C}\left(125^{\circ} \mathrm{F}\right)$ ]

\begin{tabular}{|c|c|c|c|c|c|c|}
\hline & \multicolumn{2}{|c|}{$\begin{array}{l}\text { Maximum normal } \\
\text { stress from } \\
\text { elastic analysis }\end{array}$} & \multicolumn{2}{|c|}{$\begin{array}{l}\text { Maximum normal } \\
\text { stress from } \\
\text { creep analysis }\end{array}$} & \multicolumn{2}{|c|}{$\begin{array}{l}\text { Ultimate tensile } \\
\text { stress (ref. 1) }\end{array}$} \\
\hline & $\mathrm{MPa}$ & psi & $\mathrm{MPa}$ & $\mathrm{psi}$ & $\mathrm{MPa}$ & $\mathrm{psi}$ \\
\hline \multicolumn{7}{|c|}{ Lower plate } \\
\hline $100 \mathrm{~h}$ at $177^{\circ} \mathrm{C}\left(350^{\circ} \mathrm{F}\right)$ & 76.5 & 11100 & 70.4 & 10200 & 118.4 & 17200 \\
\hline $500 \mathrm{~h}$ at $177^{\circ} \mathrm{C}\left(350^{\circ} \mathrm{F}\right)$ & 76.5 & 11100 & 60.6 & 8800 & 118.4 & 17200 \\
\hline $100 \mathrm{~h}$ at $204^{\circ} \mathrm{C}\left(400^{\circ} \mathrm{F}\right)$ & 77.2 & 11200 & 57.2 & 8300 & 106.4 & 15400 \\
\hline $450 \mathrm{~h}$ at $204^{\circ} \mathrm{C}\left(400^{\circ} \mathrm{F}\right)$ & 77.2 & 11200 & 44.6 & 6500 & 106.4 & 15400 \\
\hline $100 \mathrm{~h}$ at $260^{\circ} \mathrm{C}\left(500^{\circ} \mathrm{F}\right)$ & 78.6 & 11400 & 40.1 & 5800 & 52.1 & 7550 \\
\hline $450 \mathrm{~h}$ at $260^{\circ} \mathrm{C}\left(500^{\circ} \mathrm{F}\right)$ & 78.6 & 11400 & 36.8 & 5300 & 52.1 & 7550 \\
\hline \multicolumn{7}{|c|}{ Upper plate } \\
\hline $100 \mathrm{~h}$ at $177^{\circ} \mathrm{C}\left(350^{\circ} \mathrm{F}\right)$ & 82.0 & 11900 & 54.4 & 7900 & 118.4 & 17200 \\
\hline $500 \mathrm{~h}$ at $177^{\circ} \mathrm{C}\left(350^{\circ} \mathrm{F}\right)$ & 82.4 & 11900 & 42.4 & 6200 & 118.4 & 17200 \\
\hline $100 \mathrm{~h}$ at $204^{\circ} \mathrm{C}\left(400^{\circ} \mathrm{F}\right)$ & 84.1 & 12200 & 43.1 & 6200 & 106.4 & 15400 \\
\hline $450 \mathrm{~h}$ at $204^{\circ} \mathrm{C}\left(400^{\circ} \mathrm{F}\right)$ & 84.1 & 12200 & 40.6 & 5900 & 106.4 & 15400 \\
\hline $100 \mathrm{~h}$ at $260^{\circ} \mathrm{C}\left(500^{\circ} \mathrm{F}\right)$ & 88.2 & 12800 & 36.3 & 5300 & 52.1 & 7550 \\
\hline $450 \mathrm{~h}$ at $260^{\circ} \mathrm{C}\left(500^{\circ} \mathrm{F}\right)$ & 88.2 & 12800 & 32.7 & 4700 & 52.1 & 7550 \\
\hline
\end{tabular}




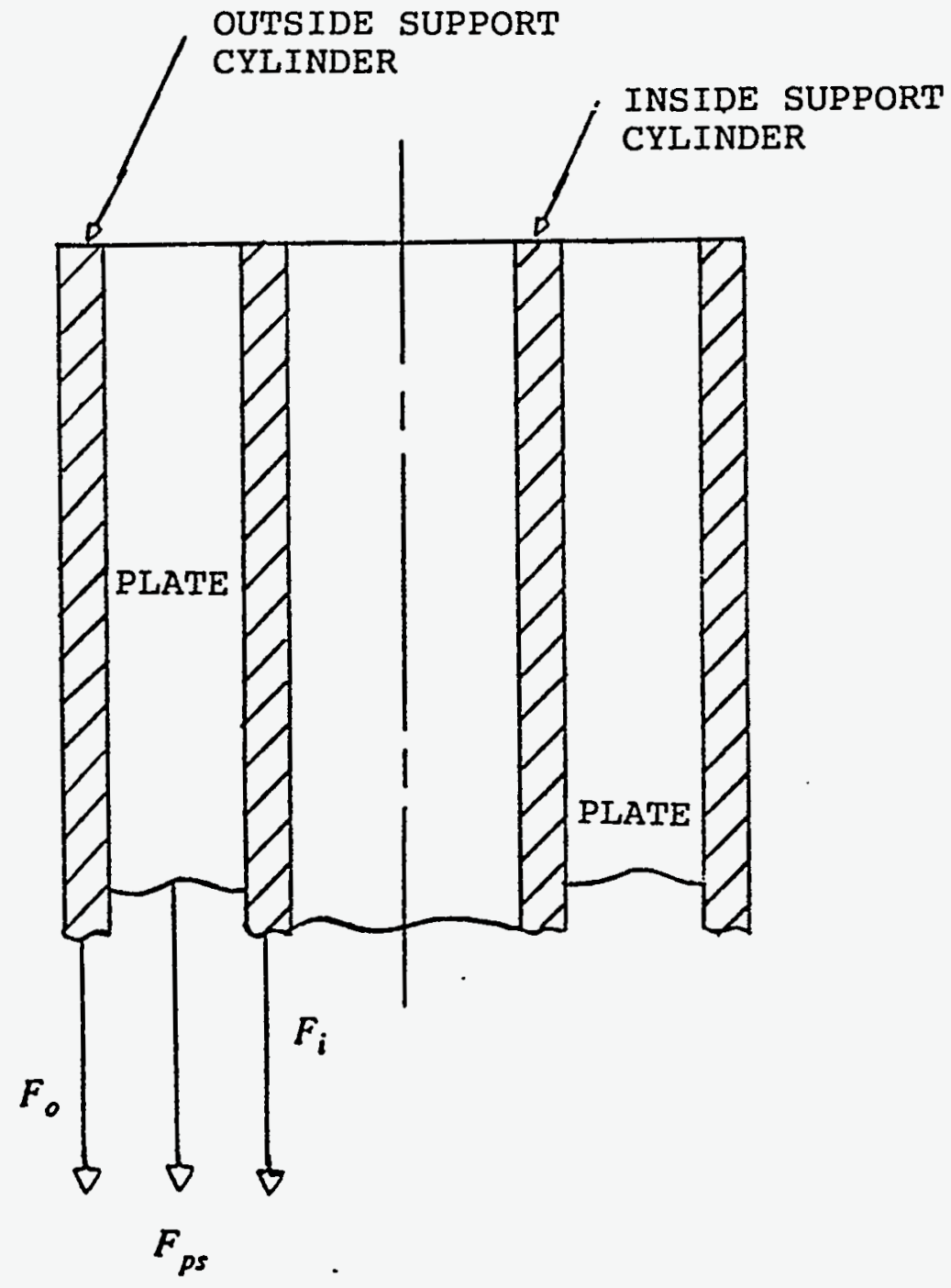

Fig. 9. Free body of longitudinal thermal forces. 
Table 5. Maximum longitudinal stress from thermal load [boundary temperature $=52^{\circ} \mathrm{C}\left(125^{\circ} \mathrm{F}\right)$ ]

\begin{tabular}{|c|c|c|c|c|c|c|}
\hline & \multicolumn{2}{|c|}{$\begin{array}{l}\text { Maximum normal } \\
\text { stress from } \\
\text { elastic analysis }\end{array}$} & \multicolumn{2}{|c|}{$\begin{array}{l}\text { Maximum normal } \\
\text { stress from } \\
\text { creep analysis }\end{array}$} & \multicolumn{2}{|c|}{$\begin{array}{l}\text { Ultimate tensile } \\
\text { stress (ref. 1) }\end{array}$} \\
\hline & $\mathrm{MPa}$ & psi & $\mathrm{MPa}$ & psi & $\mathrm{MPa}$ & psi \\
\hline \multicolumn{7}{|c|}{ Lower plate } \\
\hline $100 \mathrm{~h}$ at $177^{\circ} \mathrm{C}\left(350^{\circ} \mathrm{F}\right)$ & 59.7 & 8660 & 60.0 & 8700 & 118.4 & 17200 \\
\hline $500 \mathrm{~h}$ at $177^{\circ} \mathrm{C}\left(350^{\circ} \mathrm{F}\right)$ & 59.7 & 8660 & 52.3 & 7590 & 118.4 & 17200 \\
\hline $100 \mathrm{~h}$ at $204^{\circ} \mathrm{C}\left(400^{\circ} \mathrm{F}\right)$ & 73.0 & 10590 & 48.3 & 7000 & 106.4 & 15400 \\
\hline $450 \mathrm{~h}$ at $204^{\circ} \mathrm{C}\left(400^{\circ} \mathrm{F}\right)$ & 73.0 & 10590 & 38.6 & 5600 & 106.4 & 15400 \\
\hline $100 \mathrm{~h}$ at $260^{\circ} \mathrm{C}\left(500^{\circ} \mathrm{F}\right)$ & 99.5 & 14440 & 28.6 & 4150 & 52.1 & 7550 \\
\hline $450 \mathrm{~h}$ at $260^{\circ} \mathrm{C}\left(500^{\circ} \mathrm{F}\right)$ & 99.5 & 14440 & 22.7 & 3290 & 52.1 & 7550 \\
\hline \multicolumn{7}{|c|}{ Upper plate } \\
\hline $100 \mathrm{~h}$ at $177^{\circ} \mathrm{C}\left(350^{\circ} \mathrm{F}\right)$ & 63.8 & 9250 & 62.1 & 9000 & 118.4 & 17200 \\
\hline $500 \mathrm{~h}$ at $177^{\circ} \mathrm{C}\left(350^{\circ} \mathrm{F}\right)$ & 63.8 & 9250 & 53.8 & 7800 & 118.4 & 17200 \\
\hline $100 \mathrm{~h}$ at $204^{\circ} \mathrm{C}\left(400^{\circ} \mathrm{F}\right)$ & 77.9 & 11300 & 48.3 & 7000 & 106.4 & 15400 \\
\hline $450 \mathrm{~h}$ at $204^{\circ} \mathrm{C}\left(400^{\circ} \mathrm{F}\right)$ & 77.9 & 11300 & 38.3 & 5560 & 106.4 & 15400 \\
\hline $100 \mathrm{~h}$ at $260^{\circ} \mathrm{C}\left(500^{\circ} \mathrm{F}\right)$ & 106.3 & 15400 & 28.4 & 4120 & 52.1 & 7550 \\
\hline $450 \mathrm{~h}$ at $260^{\circ} \mathrm{C}\left(500^{\circ} \mathrm{F}\right)$ & 106.3 & 15400 & 22.7 & 3290 & 52.1 & 7550 \\
\hline
\end{tabular}




\section{SUMMARY}

All of our analyses, both elastic and creep, suggest that from a structural viewpoint the plate deflection caused by pressure loading and thermal loading is not a limiting parameter.

Stress analyses gave mixed conclusions. An elastic stress analysis because of the pressure load and the thermal load has the resulting stresses in the plane of the involute well into the yield zone and is not acceptable from an elastic viewpoint. Contrary to the elastic analysis of the stresses in the plane of the involute, a creep analysis has these stresses, which are caused by the pressure load and the thermal load, at acceptable levels. An elastic analysis of the longitudinal stresses in the plates, which are a result of the thermal load, has stresses much above the material yield stress level and therefore is unacceptable. A preliminary elastic finite element analysis of the longitudinal stresses shows stress values much above the ultimate tensile stress level. Contrary to the elastic analysis, the creep analysis predicts acceptable longitudinal stress levels.

If a designer were to use an elastic analysis to evaluate the structural suitability of the ANS plate design, the conclusion would be that the plate design is inadequate. However, the use of an elastic analysis may not be the most reasonable engineering approach.

At the same time, conclusions based on the numbers generated by the creep analysis have to be tempered. Data for materials that exhibit creep are not as consistent or as reliable as data for materials that do not exhibit creep. Assumptions used in creep analysis such as "plane sections remaining plane," "what functions best describe the stress-strain data," "small deformations," "a constant or ever increasing load function," "uniaxial data being extended to biaxial stress fields," "use of straight beam segments to represent the involute," "neglect of stress concentrations at intersection of plates with boundaries," and others suggest that tolerances associated with the results should not be too narrow. In addition, an important factor in this analysis is the assumption that an entire plate is at some average temperature. Averaging the temperature tends to smooth out stress maxima and minima. It should be emphasized that when a material yields, it also tends to smooth out the stress maxima and minima. The question is, to what extent does this smoothing of the stresses occur in the real system?

It is recommended that an experiment be designed and conducted to sort out the conflicting analyses and to give direction on what course should be followed. The test would start with fabricating an in-house involute plate. The test would be set up with a system to pressurize one side of the plate for simulating the pressure load resulting from flow. In addition, one side of the plate would be heated with a heat lamp arrangement to simulate the heating of the plate. The 
boundaries would probably require cooling to simulate the boundary temperatures. The test would be run at several temperatures for different lengths of time to assess the structural response of the plates and the adequacy of the design. 


\section{REFERENCES}

1. W. F. Swinson, C. R. Luttrell, and G. T. Yahr, An Elastic Examination of the Structural Response of the ANS Fuel Plates, ORNL/TM-12712, Martin Marietta Energy Systems, Inc., Oak Ridge Natl. Lab., March 1994.

2. W. R. Martin and J. R. Weir, Mechanical Properties of X8001 and 6061 Aluminum Alloys and Aluminum-Base Fuel Dispersion at Elevated Temperatures, ORNL-3557, Union Carbide Corp., Oak Ridge Natl. Lab., February 1964.

3. J. O. Smith and O. M. Sidebottom, Inelastic Behavior of Load-Carrying Members, John Wiley \& Sons, Inc., New York/London/Sydney, 1965. 
Appendix A: CASTIGLIANO'S THEOREMS FOR A BEAM IN BENDING 



\section{Appendix A: \\ CASTIGLIANO'S THEOREMS FOR A BEAM IN BENDING}

One of Castigliano's theorems in terms of complementary energy is

$$
\Theta_{i}=\frac{d \gamma}{d M_{i}}
$$

where $\Theta_{i}=$ rotation of couple,

$\gamma=$ complementary energy,

$M_{i}=$ moment or couple.

For a cantilever beam, Fig. A.1, with a moment or couple applied to one end (assuming small deflection),

$$
\Theta \rho=\Delta s
$$

therefore, Eq. (A.1) can be expressed as

$$
d \gamma=\frac{\Delta s}{\rho} d M
$$

or

$$
\gamma=\Delta s \int_{0}^{M} \frac{d M}{\rho}
$$

Extending Eq. (A.4) to a beam that has a variable moment along its length,

$$
\gamma=\int_{0}^{L}\left[\int_{0}^{M} \frac{d M}{\rho}\right] d s,
$$




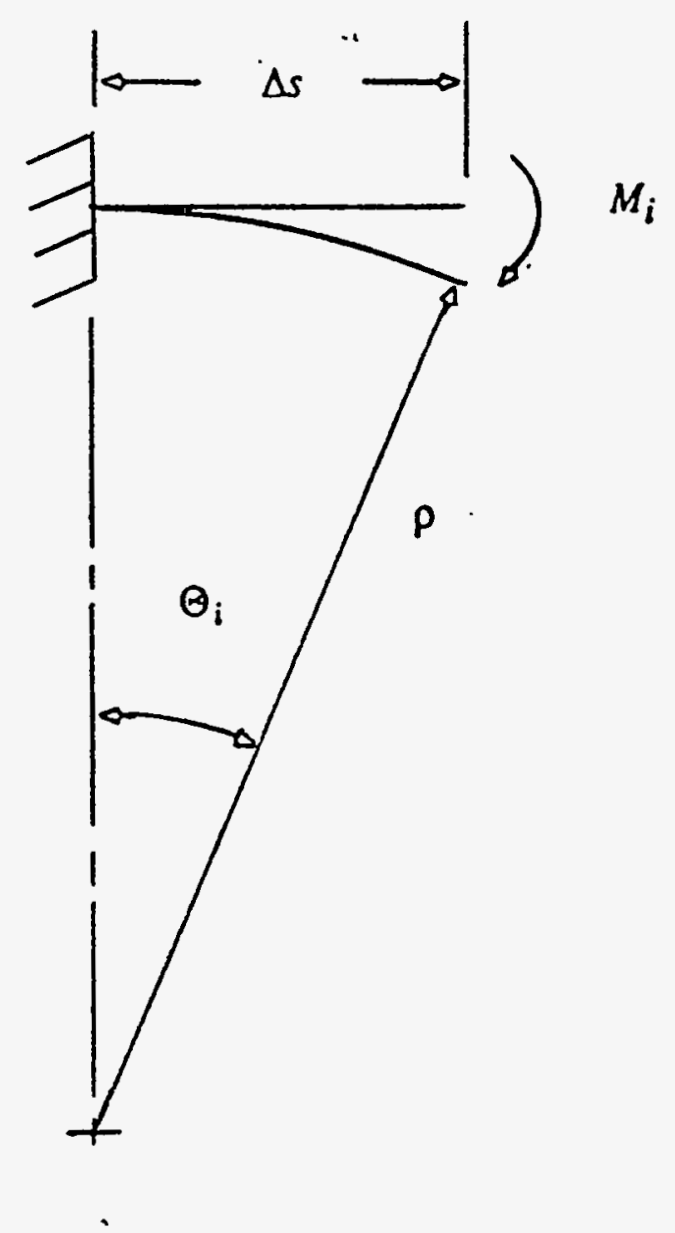

Fig. A.1. Beam element. 
where $L=$ length of beam and $d s=$ element of arc length.

Now with Eq. (A.5), Eq. (A.1) can be expressed as

$$
\Theta_{i}=\frac{d}{d M_{i}}\left\{\int_{0}^{L}\left[\int_{0}^{M} \frac{d M}{\rho}\right] d s\right\}=\int_{0}^{L} \frac{1}{\rho} \frac{\partial M}{\partial M_{i}} d s,
$$

which is Eq. (10).

The other theorem of Castigliano is

$$
q_{i}=\frac{d \gamma}{d F_{i}}
$$

where $q_{i}=$ deflection in direction of an applied force $\left(F_{i}\right)$.

Utilizing Eq. (5), Eq. (A.7) is expressed as

$$
q_{i}=\frac{d}{d F_{i}}\left\{\int_{0}^{L}\left[\int_{0}^{M} \frac{d M}{\rho}\right] d s\right\}=\int_{0}^{L} \frac{1}{\rho} \frac{\partial M}{\partial F_{i}} d s,
$$

which is Eq. (9). 
ORNL/TM-12788

\section{DISTRIBUTION}

1. C. W. Alexander

2. D. J. Alexander

3. R. R. Allen

4. E. E. Alston

5. J. L. Anderson

6. B. R. Appleton

7. R. L. Battiste

8. R. E. Battle

9. R. S. Booth

10. R. A. Brown

11. S. L. Byerly

12-16. J. H. Campbell

17. P. F. Cento

18. N. C. J. Chen

19. K. K. Chipley

20. J. A. Clinard

21. G. L. Copeland

22. J. M. Corum

23. J. R. Dixon

24. K. Farrell

25. D. K. Felde

26. M. L. Gildner

27. R. G. Gilliland

28. H. A. Glovier

29. R. C. Gwaltney
30. R. M. Harrington

31. J. B. Hayter

32. W. R. Hendrich

33. R. O. Hussung

34. D. T. Ingersoll

35-38. R. L. Johnson

39. J. E. Jones Jr.

40. R. A. Lillie

41. M. A. Linn

42. A. T. Lucas

43. C. R. Luttrell

44. M. F. Marchbanks

45. J. A. March-Leuba

46. B. S. Maxon

47. G. T. Mays

48. S. V. McGrath

49. T. J. McManamy

50. G. R. McNutt

51. R. M. Moon

52. D. G. Morris

53. D. L. Moses

54. R. E. Pawel

55. H. R. Payne

56. F. J. Peretz

57. A. B. Poole
58. C. C. Queen

59. J. S. Rayside

60. J. B. Roberto

61. M. B. Ruggles

62. T. L. Ryan

63. D. L. Selby

64. H. B. Shapira

65. M. Siman-Tov

66. W. F. Swinson

67. R. P. Taleyarkhan

68. D. W. Thiesen

69. P. B. Thompson

70. K. R. Thoms

71. C. D. West

72. D. M. Williams

73. B. A. Worley

74. G. T. Yahr

75. G. L. Yoder

76. ORNL Patent Section

77-78. Document Res. Library

79. Y-12 Technical

80-81. Laboratory Records Dept.

82. Laboratory Records (RC)

\section{EXTERNAL DISTRIBUTION}

83. R. Awan, U.S. Department of Energy, NE-473, Washington, DC 20585.

84. K. Böning, Fakultät für Physik E21, Technische Universität München, D-8046 Garching, Germany.

85. K. K. Conway, Laboratory Facilities Branch, U.S. Department of Energy, Oak Ridge Operations Office, CE-523, P.O. Box 2001, Oak Ridge, TN 37831-2001.

86. R. R. Fullwood, Bldg. 130, Brookhaven National Laboratory, Upton, NY 11973.

87. R. Gambill, Route 5, Box 220, Clinton, TN 37716.

88. A. F. Henry, Professor, Department of Nuclear Engineering, Massachusetts Institute of Technology, 167 Albany St., NW16-288, Cambridge, MA 02139

89. R. A. Hunter, Director, Office of Facilities, Fuel Cycle, and Test Programs, Nuclear Energy Division, U.S. Department of Energy, NE-47, Washington, DC 20585.

90. T. L. Kerlin, The University of Tennessee, College of Engineering, 315 Pasqua Engineering Building, Knoxville, TN 37996-2300.

91. J. A. Lake, Manager, Nuclear Engineering and Reactor Design, Idaho National Engineering Laboratory, P.O. Box 1625, Idaho Falls, ID 83415. 
92. J. E. Mays, Research and Test Reactor Fuel Elements, Babcock and Wilcox Co., P.O. Box 785, Lynchburg, VA 24505.

93. J. P. Mulkey, Division of Energy Research Reactors, Office of Nuclear Energy, U.S. Department of Energy, NE-473, Washington, DC 20585.

94. W. T. Oosterhuis, Materials Sciences Division, Office of Basic Energy Sciences, Office of Energy Research, U.S. Department of Energy, ER-132, Washington, DC 20585.

95. H. Reutler, Siemens, Friedrich-Ebert Strasse, D-5060 Bergish, Gladback-1, Germany.

96. J. M. Ryskamp, Idaho National Engineering Laboratory, P.O. Box 1625, Idaho Falls, ID 83415-3885.

97. J. L. Snelgrove, Coordinator, Engineering Applications, RERTR Program, Argonne National Laboratory, 9700 South Cass Avenue, Argonne, IL 60439.

98. I. Thomas, Director, Materials Science Division, Office of Energy Research, U.S. Department of Energy, ER-13, Washington, DC 20585.

99. U.S. Department of Energy, ANS Project office, Oak Ridge Operations Office, FEDC, MS-8218, P.O. Box 2009, Oak Ridge, TN 37831-8218.

100. H. G. Wood, III, Associate Professor, Department of Mechanical and Aerospace Engineering, Thornton Hall, University of Virginia, Charlottesville, VA 22901.

101. Office of Assistant Manager for Energy Research and Development, U.S. Department of Energy, Oak Ridge Operations Office, P.O. Box 2001, Oak Ridge, TN 37831.

102-103. Office of Scientific and Technical Information, P.O. Box 62, Oak Ridge, TN 37831. 